\title{
МЕДІАТЕХНОЛОГІї
}

Visn. Lviv. Univ., Ser. Zhurn. 2020: 47; 189-199 • DOI: http://dx.doi.org/10.30970/vjo.2020.47.10518

УДК 316.77:004.624

\section{МЕДІЙНИЙ «ПОРЯДОК ДЕННИЙ» У ВИСВІТЛЕННІ ЗАЯВ \\ УКРАЇНСЬКИХ ПОЛІТИЧНИХ ЛІДЕРІВ (НА МАТЕРІАЛАХ 2014-2019 рр.)}

\author{
Артем Захарченко \\ Інститут журналістики \\ Київського національного університету імені Тараса Шевченка, \\ вул. Юрія Іллєнка, 36/1, 02000, Київ, Україна \\ e-mail: artem.zakh@gmail.com \\ https://orcid.org/0000-0002-3877-8403 \\ Олена Захарченко \\ Центр контент-аналізу, \\ вул. Велика Васильківська, 30-в, оф. 1, 01004, Київ, Украӥна \\ e-mail: olena.amoli@gmail.com \\ https://orcid.org/0000-0001-8479-8977
}

Це дослідження пропонує методику кількісного оцінювання медійного порядку денного у висвітленні заяв та дій українських політиків. Запропоновано шкалу, базовану на розробленій конфліктологами шкалі світоглядів українців, яка дає змогу легко вирахувати і візуалізувати, яким проблемам присвячено цитовані в медіа вислови політичних діячів. Валідність цієї методики продемонстровано на двох прикладах: ми виміряли медійні порядки денні ключових обговорюваних на той час претендентів на посаду президента України та інших впливових чиновників у червні-листопаді 2018 року, а також порівняли відтворену у ЗМІ проблематику висловлювань п'ятого і шостого президентів України протягом перших місяців їхнього перебування на цій посаді.

Ключові слова: порядок денний; українські медіа; шкала світоглядів; вибори; медіазгадування.

\section{Постановка проблеми}

Поняття «порядку денного» (agenda) перебуває на перетині зацікавлень дослідників комунікації та політологів. Цей термін започаткували М. МакКомбс та Д. Шоу 1972 року, довівши르, що суспільні проблеми, які найчастіше висвітлюються в медіа,

\footnotetext{
1 McCombs, M. B. E. and Shaw, D. L. (1972) THE AGENDA-SETTING FUNCTION OF MASS MEDIA, The Public Opinion Quarterly. Oxford University Press. doi: 10.2307/2747787.
}

(C) Захарченко А., Захарченко О., 2020 
видаються читачам та глядачам важливішими. Тому, з одного боку, для політиків він $€$ інструментом впливу на результати виборів та на політичний курс держави ${ }^{2}, 3$ іншого - цей вплив здійснюється передовсім через медіа та соціальні мережі ${ }^{3}$.

Проблеми, які порушують політики, згодом безпосередньо впливають на наше життя. На побутовому рівні існує думка, що політики рідко виконують обіцянки, а тому не варто зважати на їхню передвиборчу риторику. Однак існує чимало прикладів, які це твердження спростовують. Скажімо, проросійська риторика Віктора Януковича на виборах 2010 року вилилася у закон про мову, а згодом і в заклик до Росії ввести війська. Відтак, ігнорувати «порядок денний» не можна.

Проблеми, про які говорять політики, можуть зацікавити аудиторію напряму за допомогою реклами або соціальних мереж, або ж опосередковано - через журналістський контент. Відтак, розрізняють «порядок денний» влади (які питання вона намагається вирішувати), громадський (що саме важливе для великих груп людей), та медійний - проблеми, про які пишуть медіа.

Все вищесказане і зумовлює актуальність нашої роботи, метою якої є розробка такої модифікації використовуваних у світі методів визначення медійного порядку денного у висвітленні політиків, яка би дозволила застосовувати її в українських умовах. Складовою частиною цієї мети $є$ апробація запропонованої методики на вітчизняному матеріалі, отримання за її допомогою даних про медійний «порядок денний» у висвітленні політиків та доведення можливості змістовного аналізу цих даних.

Об’єктом нашого дослідження є порядок денний, який формували провідні українські медіа при висвітленні діяльності відомих політиків протягом 2014-2019 років, у знакові періоди розгортання новітньої української історії. Відповідно, предмет дослідження - масив висловів політиків, трансльованих у медіа впродовж зазначеного періоду.

\section{Теоретичне підгрунтя}

Інструментальної цінності порядку денному надає поняття володіння проблемами (agenda ownership). Ідеться про позитивну асоціацію між суспільним викликом та політиком, який здатен в очах виборців цей виклик подолати. Відповідно до концепції Белангера і Мегід, коли партія вирішує якусь проблему, вплив такого факту на бажання проголосувати за цю партію пропорційний тому, наскільки важливою $\epsilon$ ця проблема у свідомості людини ${ }^{4}$. Але сила цього впливу у різних партій різна. Деякі партії менше залежать від володіння актуальними проблемами, у такому випадку важливішими можуть бути інші фактори: харизма, успішність тощо. Працює також «механізм покарання», коли в суспільстві є думка, що якась партія не спроможна вирішити цю проблему, а це зменшує шанси на ї̈ обрання.

Концепція володіння порядком денним яскраво виявлялася на Президентських виборах в Україні 2019 року, коли троє лідерів перегонів обрали три протилежні питання: Петро Порошенко - проблему захисту України від окупанта, Юлія Тимо-

\footnotetext{
2 Boydstun, A. E. (2013) Making the News: Politics, the Media, and Agenda Setting. Chicago: University of Chicago Press.

3 Russell Neuman, W. et al. (2014) 'The Dynamics of Public Attention: Agenda-Setting Theory Meets Big Data', Journal of Communication, 64(2), pp. 193-214. doi: 10.1111/jcom.12088.

${ }_{4}$ Bélanger, É. and Meguid, B. M. (2008) 'Issue salience, issue ownership, and issue-based vote choice', Electoral Studies, 27(3), pp. 477-491. doi: 10.1016/j.electstud.2008.01.001.
} 
шенко - боротьби з бідністю. Володимир Зеленський став феноменальним прикладом політика, який мав «нульовий» порядок денний, тобто - за нього голосували прибічники абсолютно різних поглядів на світ ${ }^{5}$.

Роллю медіа у формуванні порядку денного не можна нехтувати навіть в умовах розвитку соціальних мереж, а отже, активної прямої комунікації між політиками та виборцями. Адже взаємовплив медійного, соцмедійного, суспільного, владного, опозиційного порядків денних завжди є складним багатовекторним процесом. Відносна сила і напрямок таких впливів можуть кардинально змінюватися у конкретній країни в конкретний час і залежати, скажімо, від кількості партій або учасників, які змагаються на виборах, від розвиненості і структури медіа, від державного устрою і структури країни ${ }^{6}$.

При цьому відомо 7 , що медіа не завжди пропорційно висвітлюють ті питання, які намагаються просувати кандидати. На матеріалах виборів у США дослідники доводять, що, хоча у деякі роки кандидати від Демократичної партії США з однаковою інтенсивністю просували «свої» проблеми та проблеми республіканців, медіа цитували висловлювання цих депутатів переважно у зв'язку з їхніми власними питаннями, визнаючи лише їхню експертизу.

Відтак, постає питання адекватного вимірювання порядку денного відповідно до характеру проблем, які порушують політики. Існує загальноприйнята шкала, яку використовують для міжнародних порівнянь ${ }^{8}$. Але для внутрішнього використання у країнах вона надмірна. Приміром, для досліджень у США часто використовують спрощену одновимірну шкалу, значення якої змінюються від «правих» проблем (традиційні цінності, економічна свобода та ін.) до «лівих» (соціальний захист, екологія тощо). Для України такий підхід неприйнятний, адже ставлення до економіки та традиційних цінностей не є визначальними у виборчій риториці політиків. Тут варто звернутися до дослідження К. Коростеліної, яка, вивчаючи національні наративи українців, розташувала їх у таких-от вимірах: «проукраїнське - проросійська ідеологія», «гомогенне - гетерогенне суспільство» та «громадянська - етнічна концепція держави» ${ }^{9}$ Візуалізацію дво- і більше вимірного простору політичної ідеології розробили 1983 року Пул і Розенталем ${ }^{10}$.

5 Zakharchenko, A. et al. (2019) 'Under the conditions of non-agenda ownership: Social media users in the 2019 Ukrainian presidential elections campaign', CEUR Workshop Proceedings, 2392, pp. 199-219.

6 Tedesco, J. C. (2005) 'Issue and strategy agenda setting in the 2004 presidential election: Exploring the candidate-journalist relationship', Journalism Studies, 6(2), pp. 187-201. doi: 10.1080/14616700500057270.

Baumann, H. C., Zheng, P. and McCombs, M. (2018) 'First and second-level agenda-setting in the 2014 Indian general election: a time-series analysis of party-media relation', Asian Journal of Communication. Taylor \& Francis, 28(2), pp. 205-226. doi: 10.1080/01292986.2017.1390773.

7 Petrocik, J. R., Benoit, W. L. and Hansen, G. J. (2003) 'Issue Ownership and Presidential Campaigning, 1952-2000', Political Science Quarterly, 118(4), pp. 599-626.

8 CAP Topics - Comparative Agendas Project (no date). Available at: https://www.comparativeagendas. net/pages/master-codebook

9 Korostelina, K. V. (2014) Constructing the narratives of identity and power: Self-imagination in a young Ukrainian nation. Lanham: Lexington Books.

${ }^{10}$ Poole, K. T. and Rosenthal, H. (1983) 'A Spatial Model for Legislative Roll Call Analysis', American Journal of Political Science, 29(2), pp. 357-384. doi: 10.2307/2111172. 


\section{Методологічна основа дослідження}

Вивчаючи цитування у ЗМІ виступів політиків у медіа, ми обрали для дослідження два набори даних, які різнобічно характеризують особливості такої комунікації. Перший - це передвиборча комунікація до оголошення офіційного старту електоральної кампанії. Часові рамки аналізу: 28 травня - 11 листопада 2018 року. До моніторингу потрапили ключові персони, які фігурували у президентських рейтингах, а також кілька ТОП-посадовців, що активно формують владний порядок денний.

Другий масив даних стосувався порівняння перших місяців роботи п'ятого та шостого президентів України: Петра Порошенка та Володимира Зеленського. Ці двоє президентів почали керувати Україною за різних умов, хоча обоє мали спільну найбільшу проблему: збройну агресію РФ. Перший місяць вважається одним із найпоказовіших, i його підсумки активно обговорюються в медіа. Отож, часовими рамками другого дослідження стали періоди, відповідно, 8 червня - 7 липня 2014 та 21 травня - 20 червня 2019 рр. для кожного з президентів.

Дані про цитування кожного із політиків були отримані за допомогою моніторингової системи «Медіатека». До вибірки для отримання першого набору даних ми включили такі медіа: центральне телебачення, суспільно-політична центральна преса, а також стандартна вибірка Центру контент-аналізу «ТОП-10 українських онлайн-медіа», до якої входять: ТСН, Українська правда, Корреспондент, 24.uа, Цензор, Страна, Сегодня, Ліга, Дело, Новое время.

Загалом за цей період виявлено понад 14 тис. публікацій, що містили позиції політиків стосовно певних суспільних проблем.

Другий набір даних ми отримали з меншої вибірки, адже нашою задачею $є$ випробування методики за різних вихідних умов. Отож, тут ми аналізували публікації 5 онлайн-медіа різного спрямування, як за внутрішньополітичними, так і за зовнішньополітичними симпатіями, 5 канал, Уніан, Вести, Українська правда, Ліга. Серед усіх публікацій, які вийшли на цих п'яти ресурсах і містили згадування прізвища президента (відповідно, 2014 року - Порошенка, і 2019 року - Зеленського), ми відібрали у випадковий спосіб по тисячі публікацій з понад 11 тисяч у кожному виданні. Відтак, похибка вибірки не перевищує $3 \%$.

На основі первинного оглядового вивчення двох описаних вище масивів і співвіднесення отриманих результатів з картою національних наративів ми розділили всі суспільні проблеми, які порушують у медіапросторі українські політики, на п'ять умовних категорій:

- патріотичні, а також прозахідний вектор політики (освіта, культура, історія, релігія у контексті національної чи європейської ідентичності, а також армія, безпека, відносини зі США, ЄС, НАТО);

- російський вектор політики (мир з Росією, переговори з РФ, а також історія, культура та релігія в контексті російської або радянської ідентичності);

- соціальні (підвищення зарплат, пенсій, здешевлення комунальних послуг, споживчі права і можливості, а також заперечення названих у наступному пункті пропозицій);

- ліберальні (вільний продаж землі, розвиток економіки, дерегуляція, запровадження інновацій, свободи слова, прав людини, децентралізація, адмінреформи, а також заперечення названих у попередньому блоці пропозицій);

- правопорядок та боротьба з корупцією. 
Перші дві пари ми вважали взаємно протилежними, тобто, розташованими на протилежних кінцях двох осей: відповідно, геополітичної та економічної. П'ятий пункт - необхідний для будь-якого іншого порядку денного. Тому при візуалізації питання корупції, справедливих судів тощо наносилася не на координатну вісь, а відтворювалася у форматі сірого кола.

Окрім того, робота над другим сетом даних спонукала нас виділити таку категорію, як «неполітичний порядок денний». Сюди ми відносили повідомлення, які не стосуються суспільних проблем, а отже, можуть слугувати для того, щоб відволікати від них громадян: споживання шаурми, участь у концертах тощо. Інтенсивність уваги медіа у цих питаннях візуалізована як червоне коло.

Звісно, Україна має й інші проблеми, окрім наведених. Але ніхто з топових політиків не висловлювався, скажімо, про екологію. Або ж топові медіа такі висловлювання не цитували.

Використовуючи описані вище категорії, двоє тренованих кодувальників Центру контент-аналізу кодували наявність в усіх публікаціях масиву згадувань з ознаками кожної із п’яти (для першого набору даних) і шести (для другого) описаних вище категорій. Отримані результати були оброблені статистично і візуалізовані у вигляді діаграм.

\section{Виклад основного матеріалу дослідження}

Аналіз першого набору даних показав: 2018 року політики відчували запит не тільки на патріотичну, але і на ліберальну риторику. Навіть політикам з традиційно соціальною риторикою було замало дати традиційну обіцянку зниження цін: потрібно було іще й згадати про реформи, хай навіть і не уточнюючи, як саме їх планують проводити. Непропорційно висока порівняно з іншими політиками увага до соціальних проблем була спостережена у О.Ляшка, у якого в досліджувані місяці рейтинг погіршився з 6,1\% до 4,9\% відповідно до усереднених показників опитувань відомих українських соціологічних служб.

Отож, найцитованіші політики мали дуже схожі діаграми розподілу уваги до питань порядку денного: патріотичні, з приблизно однаковим рівнем уваги до ліберальних і соціальних проблем (Див. рис.1.). Навіть ті діячі, яких звикли вважати «соціально-орієнтованими», скажімо, Ю. Тимошенко, намагалися балансувати свої порядки денні і говорити не лише про ціну на газ, а й, щонайменше, про інновації. Тому схеми риторики опонентів - П. Порошенко та Ю. Тимошенко - майже ідентичні, схоже також поводилися В. Гройсман та А. Аваков.

Для прикладу, П. Порошенко (Puc.2) найбільше користувався патріотичним порядком денним, що був присвячений, передовсім, протидії Росії: зміцненню оборони, визволенню політв'язнів, протистоянню між «Нафтогазом України» та «Газпромом», ситуації на фронті та Азовській кризі, а також пошуку міжнародної підтримки в питанні протидії російській агресії. Також в патріотичному «порядку денному» питання помісної церкви, питання вступу в НАТО, розвиток оборонної галузі, частково - історія та освіта. Соціальний порядок у чинного на той час президента активізувався під кінець періоду у зв'язку з тарифами на газ та субсидіями. Ліберальний «порядок денний» полягав у відкритті нових заводів, ремонті доріг, залученні інвестицій, особливо резонансною була заява про залучення на український ринок компанії IKЕА. Згадати про боротьбу з корупцією дозволив Антикорупційний суд, але пізніше ця тема активізувалася тільки у зв’язку з поточними подіями. 

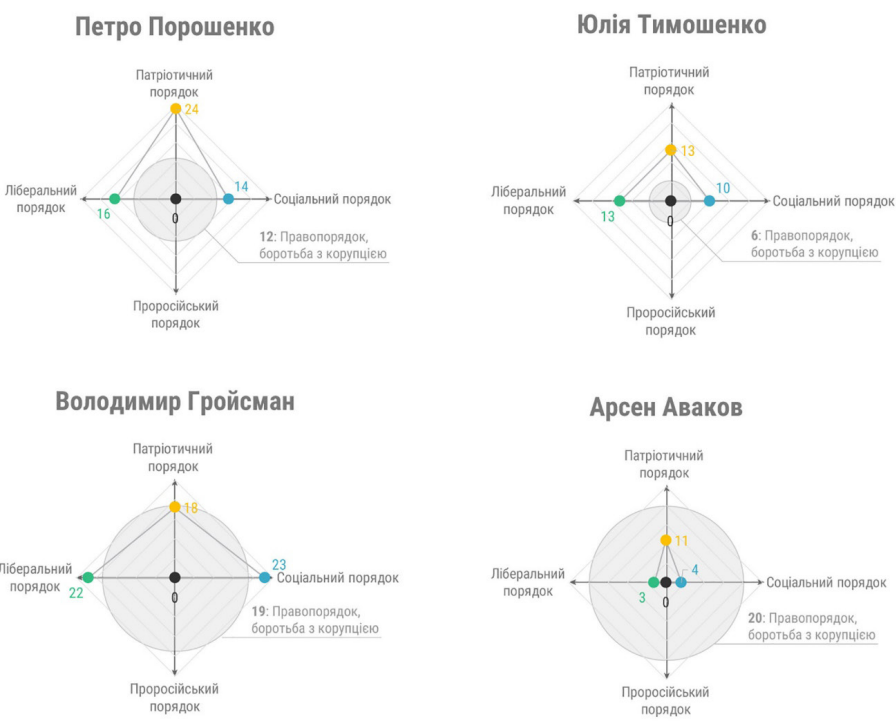

Рис. 1. Діаграми розподілу уваги до питань порядку денного чотирьох найцитованіших політиків першого досліджуваного періоду, кількість тижнів зі згадуванням таких питань.

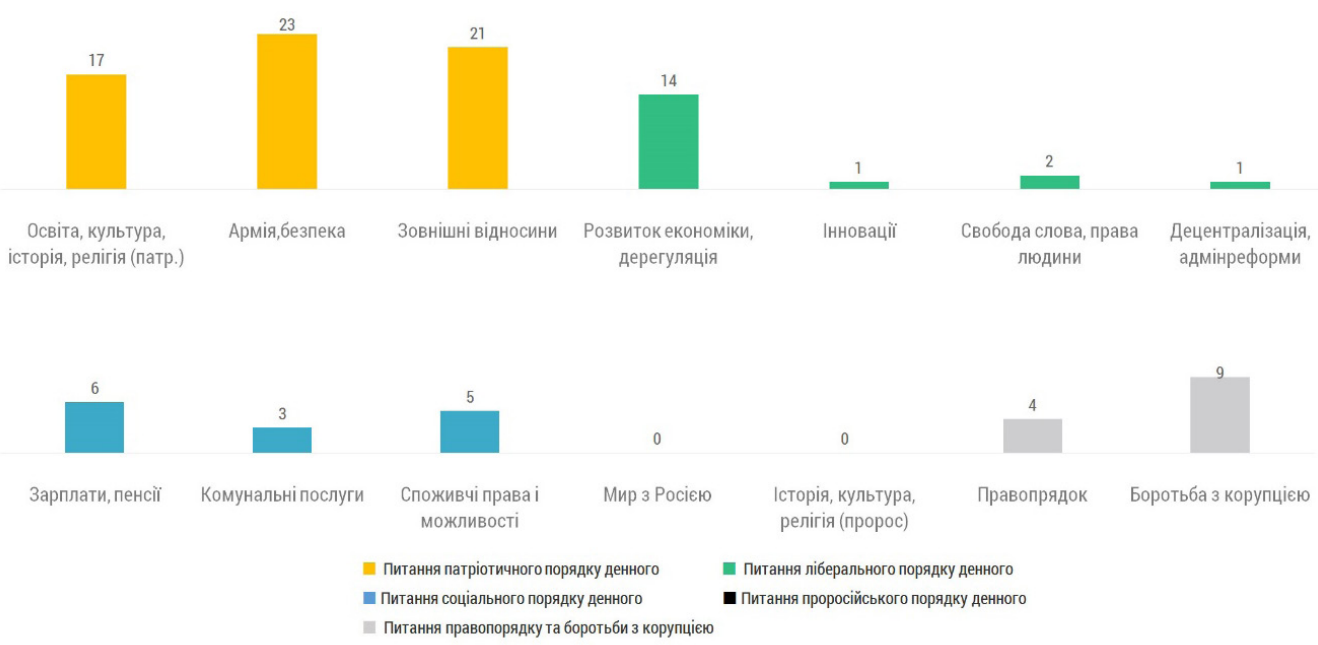

Рис.2. Детальний тематичний розподіл питань порядку денного, щчодо яких медіа ичитували П. Порошенка у першому періоді дослідження, кількість тижнів зі згадуванням таких питань.

На той час основною конкуренткою чинного президента вважалася Юлія Тимошенко. Ї̈̈ активність була досить слабкою на початку досліджуваного періоду, але до кінця листопада зросла завдяки проведенню «форумів», коментуванню поточних резонансних подій: іiї цитати дедалі частіше почали підхоплювати медіа. Її найпоши- 


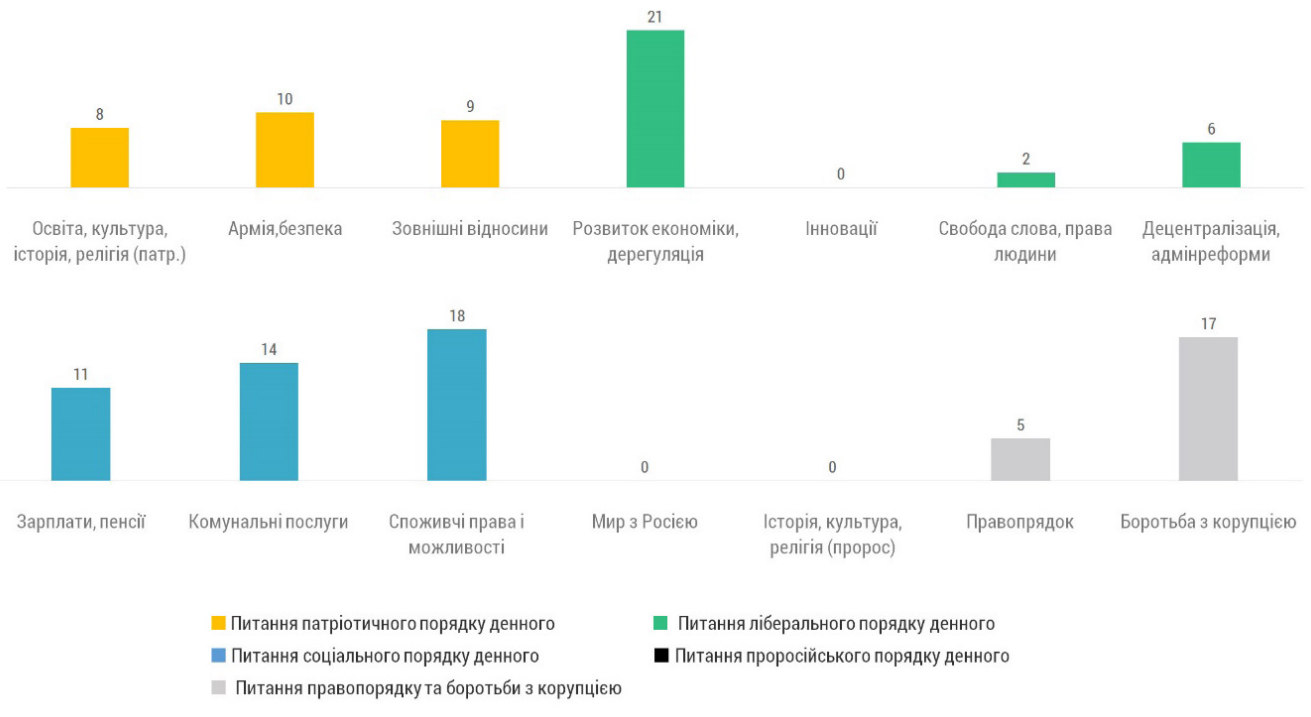

Рис.3. Детальний тематичний розподіл питань порядку денного, щзодо яких медіа цчитували Ю. Тимошенко у першому періоді дослідження, кількість тижнів зі згадуванням таких питань.

рюваніший «порядок денний» - ліберальний, зокрема, вона говорила про зміну Конституції, інновації, нові пропозиції щодо розвитку економіки. Патріотичний «порядок денний» пожвавішав наприкінці досліджуваного періоду, коли з'явились теми армії, оборони, поїздка на Схід. Соціальні теми посилилися з загостренням теми опалювального сезону та зростанням тарифів на газ. Теми щодо боротьби 3 корупцією з’являються фрагментами: при голосуванні за Антикорупційний суд, критиці «Нафтогазу України» тощо.

Проаналізувавши аналогічно висвітлення всіх досліджуваних політиків, ми змогли виокремити три групи кандидатів зі схожими порядками денними.

- Антикорупційно-ліберальні;

- Патріотичні, з великою домішкою соціальних питань (окремо - Олег Ляшко як найбільш «соціальний»);

- Проросійські, розділені за типом риторики на «соціалістів» та «лібералів».

Отримані результати ми візуалізували на Рис.4. Методика побудови цієї діаграми така: від кількості тижнів, у яких кожен політик порушував проблеми ліберального порядку денного, віднімалася кількість тих тижнів, коли порушувана була соціальна проблематика. Аналогічна процедура відбувалася з відніманням проросійського порядку денного від патріотичного.

Потім дві отримані різниці, а також кількість тижнів, у яких згадувалася проблематика правопорядку та боротьби з корупцією, нормалізувалися через ділення на максимальне значення уваги політика до одного 3 п’яти типів порядків денних. Так отримано було значення трьох координат політика. Дві з них відкладені на координатній площині, третю схарактеризовано кольором точки та числом на ній. 


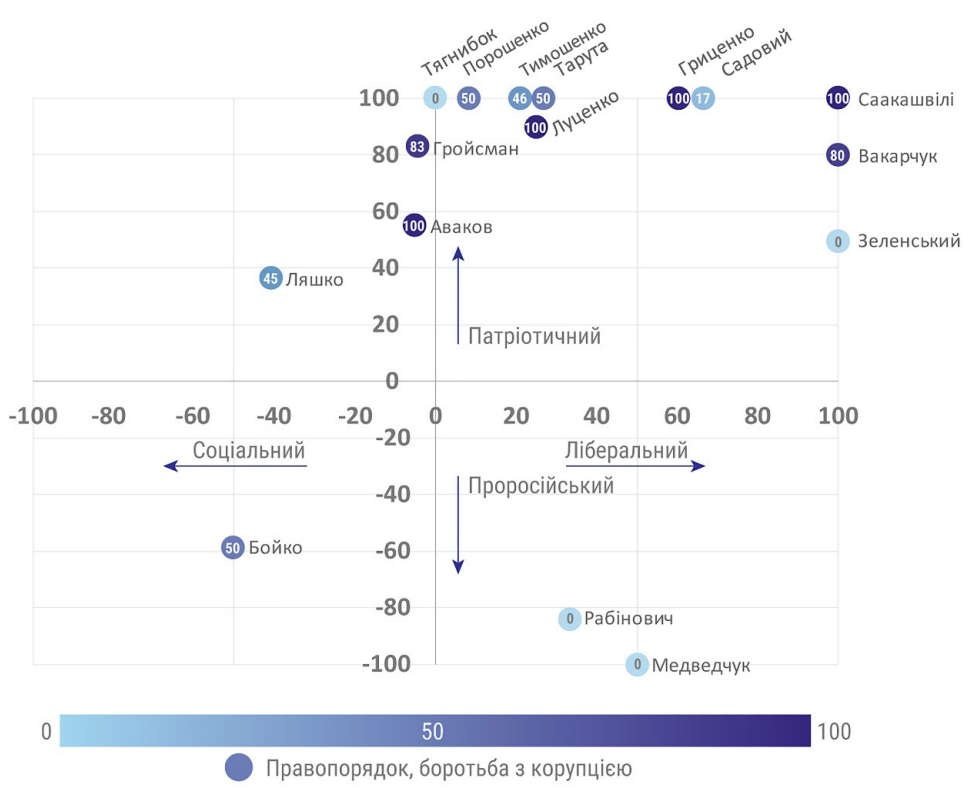

Рис.4. Узагальнена тривимірна карта важливості кожної з тем у порядку денному політиків у першому періоді дослідження.

У підсумку чітко видно, що, скажімо, А. Гриценко та А. Садовий виявилися майже ідентичні в порядку денному, а от С. Вакарчук дещо від них відрізнявся, i був ближчим до В. Зеленського. Проросійський «порядок денний» представляють три персони, які згодом висунули єдиного кандидата. Цікаво, що риторика Ю. Бойка дуже сильно відрізнялася від В. Медведчука та В. Рабіновича: він набагато більше говорить про соціальні проблеми, тоді як інші двоє - про перезапуск економіки. Ю. Бойко набагато більше подібний до О. Ляшка. Ці двоє порушують ті самі питання, тільки у Ляшка вони відформатовані в гостро патріотичному ключі, а у Бойка - у виразно проросійському.

Цікаво, що в досліджуваний період медіа оприлюднювали цитати всіх досліджуваних політиків про боротьбу з корупцією, окрім чотирьох: В. Зеленського, О. Тягнибока, В. Рабіновича та В. Медведчука.

Досвід застосування пропонованої шкали для другого масиву даних також виявився позитивним. Скажімо, візуалізація порядку денного, який просували обидва президенти упродовж першого місяця роботи, в обох - надзвичайно схожа: акцент на патріотичних проблемах, а також увага до ліберального порядку денного (Puc.5). Розбіжності виявляються за умов детальнішого аналізу порушуваних тем.

Зокрема, протидія російській агресії та угода про асоціацію з ЄС (обидві стосуються патріотичного порядку денного, згідно з нашою класифікацією) для Петра Порошенка стали ключовими темами висловлювань та дій вже у перший місяць роботи. Навіть ліберальний та соціальний «порядок денний» великою мірою були підпорядковані цьому ключовому напрямку, як-от виплати компенсацій родичам загиблих військових та відновлення житла на Донбасі. Інформаційними приводами для 

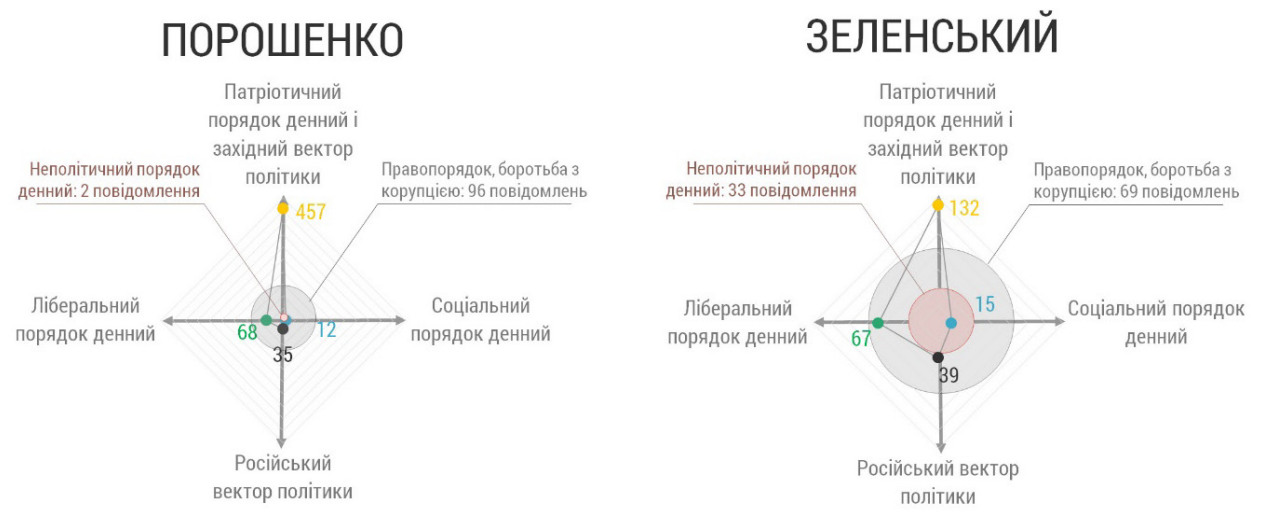

Рис.5. Діаграми розподілу уваги до питань порядку денного

Петра Пороченка та Володимира Зеленського у другому досліджуваному періодi, кількість публікацій з такими питаннями

згадування всіх трьох порядків денних ставали переважно конкретні рішення та дії: оголошення перемир'я, виступи на засіданнях міжнародних організацій, згодом відновлення АТО.

Спектр тем, на які встиг висловитися Володимир Зеленський, набагато ширший. При переважанні патріотично-західного вектору, він все-таки встиг поширити заяви щодо усіх без винятку питань порядку денного, продемонструвавши системний підхід до роботи з усіма частинами зацікавленої аудиторії. 3 іншого боку, серед інформприводів його цитувань було мало остаточних конкретних рішень, якщо не брати до уваги кадрові призначення. Здебільшого це обіцянки та плани.

Ще однією помітною різницею між порядками денними двох президентів стала велика кількість неполітичних тем у згадуваннях Зеленського. У вибірці з висловлювань Порошенка зафіксовано лише дві новини на цю тему: вони стосувалися офіційного прийому в Арсеналі. Зеленський постійно фігурує в контексті висловлювань про шаурму на автозаправній станції, появи його на розважальних концертах, екскурсій будівлею Адміністрації президента тощо.

Результати і перспективи подальших досліджень

У підсумку ми бачимо, що шкала вимірювання порядку денного українських політиків або партійних брендів, яку ми розробили, доволі добре характеризує коло проблем, які вони просувають і якими намагаються «володіти» у суспільній свідомості. Скажімо, на основі використання цієї шкали без жодного додаткового аналізу можна робити аргументовані висновки про групування політиків зі схожим порядком денним, а також про актуалізацію політиками певних суспільних проблем у процесі виборчої кампанії. В інших випадках, зокрема, коли «портрети» двох державних діячів схожі, потрібно доповнювати аналіз іншими методами, зокрема, вивчати якість інформаційних приводів, що спонукали висвітлювати певні питання порядку денного, а також, можливо, інші характеристики тем.

Обмеженням цього методу $є$, передусім, його релевантність лише у поточному політичному періоді. Історичний процес на теренах України може кардинально змінити шкалу світоглядів українців, а отже й «порядок денний» їхніх політичних лідерів. 


\section{Висновки}

«Порядок денний» медійного висвітлення українських політиків є комплексним явищем, вивчення якого потребує урахування національної ментальності, історичних особливостей досліджуваного періоду і цілей учасників політичної комунікації. Окрім того, звісно, варто розрізняти медійний і суспільний порядки денні: увага медіа до заяв політика про різні суспільні проблеми не означає, що і виборці сприймають його саме в контексті цих проблем. Виборці можуть не довіряти розмовам політика про ліберальні цінності і традиційно сприймати його лише у контексті соціальної або патріотичної проблематики. Часом сприйняття політика взагалі абстраговане від його порядку денного і фокусується лише довкола харизми.

Проте, враховуючи всі зазначені аргументи, наш метод дає кількісні характеристики порядку денного політичних гравців, а відтак, і матеріал для подальшого аналізу поведінки цих ньюзмейкерів. Його можуть застосовувати і політологи для вивчення передвиборчих перспектив кандидатів та зміни актуальності різних суспільних проблем у громадській свідомості, і дослідники комунікацій для з'ясування особливостей висвітлення важливих політичних процесів різними категоріями медіа.

\section{REFERENCES}

1. Baumann, H. C., Zheng, P. and McCombs, M. (2018) 'First and second-level agendasetting in the 2014 Indian general election: a time-series analysis of party-media relation', Asian Journal of Communication. Taylor \& Francis, 28(2), pp. 205-226. doi: 10.1080/01292986.2017.1390773.

2. Bélanger, É. and Meguid, B. M. (2008) 'Issue salience, issue ownership, and issue-based vote choice', Electoral Studies, 27(3), pp. 477-491. doi: 10.1016/j.electstud.2008.01.001.

3. Boydstun, A. E. (2013) Making the News: Politics, the Media, and Agenda Setting. Chicago: University of Chicago Press.

4. CAP Topics - Comparative Agendas Project (no date). Available at: https://www. comparativeagendas.net/pages/master-codebook

5. Korostelina, K. V. (2014) Constructing the narratives of identity and power: Self-imagination in a young Ukrainian nation. Lanham: Lexington Books.

6. McCombs, M. B. E. and Shaw, D. L. (1972) THE AGENDA-SETTING FUNCTION OF MASS MEDIA, The Public Opinion Quarterly. Oxford University Press. doi: $10.2307 / 2747787$.

7. Petrocik, J. R., Benoit, W. L. and Hansen, G. J. (2003) 'Issue Ownership and Presidential Campaigning, 1952-2000', Political Science Quarterly, 118(4), pp. 599-626.

8. Poole, K. T. and Rosenthal, H. (1983) 'A Spatial Model for Legislative Roll Call Analysis', American Journal of Political Science, 29(2), pp. 357-384. doi: 10.2307/2111172.

9. Russell Neuman, W. et al. (2014) 'The Dynamics of Public Attention: Agenda-Setting Theory Meets Big Data', Journal of Communication, 64(2), pp. 193-214. doi: 10.1111/ jcom.12088.

10. Tedesco, J. C. (2005) 'Issue and strategy agenda setting in the 2004 presidential election: Exploring the candidate-journalist relationship', Journalism Studies, 6(2), pp. 187-201. doi: $10.1080 / 14616700500057270$. 
11. Zakharchenko, A. et al. (2019) 'Under the conditions of non-agenda ownership: Social media users in the 2019 Ukrainian presidential elections campaign', CEUR Workshop Proceedings, 2392, pp. 199-219.

\title{
MEDIA AGENDA IN THE COVERAGE OF UKRAINIAN POLITICAL LEADERS` STATEMENTS (ON MATERIAL OF YEARS 2014-2019)
}

\author{
Artem Zakharchenko \\ Institute of Journalism Taras Shevchenko National University of Kyiv \\ Yuriia Illienka str., 36/1, 02000, Kyiv, Ukraine \\ e-mail: artem.zakh@gmail.com \\ https://orcid.org/0000-0002-3877-8403 \\ Olena Zakharchenko \\ The Content Analysis Center \\ 30-в Velyka Vasylkivska str, \#1, 01004, Kyiv, Ukraine \\ e-mail: olena.amoli@gmail.com \\ https://orcid.org/0000-0001-8479-8977
}

The purpose of our investigation is a modification of known techniques used to determine the media agenda in the coverage of statements and actions of politicians, which would be suitable to be applied in the Ukrainian context. An integral part of this goal is the validation of the proposed methodology by using it to analyze two data sets from real Ukrainian communication practice. The developed scale is based on a scale of Ukrainians' outlooks developed by the conflict scientists. This enables to calculate and visualize the issue sets used by politicians who are quoted in the media.

The validity of this technique is proved by two examples. First, we measured the media agendas of key potential candidates of Ukrainian 2019 presidential elections and other influential Ukrainian officials in June-November 2018. Second, we compared the issue sets propelled into media by the fifth and sixth presidents of Ukraine Petro Poroshenko and Volodymyr Zelenskyi during their first months on this position. The first example showed that in 2018, before the official launch of the election campaign, all Ukrainian politicians could be divided into three groups of candidates with similar agendas.

- Anti-corruption / liberal agenda.

- Patriotic, with considerable admixture of social issues.

- Pro-Russian, divided into «socialists» and «liberals.»

In the second case, we found that the two presidents' media agendas were, at first glance, very similar, but in fact, very different in their detailed structure and the reasons of media attention.

Key words: agenda; Ukrainian media; scale of worldviews; election; media mentions. 